\title{
Antisense molecules: A new class of drugs
}

\author{
Daniel P. Potaczek, MD, PhD,* Holger Garn, PhD,* Sebastian D. Unger, and Harald Renz, MD Marburg, Germany
}

\begin{abstract}
An improved understanding of disease pathogenesis leads to identification of novel therapeutic targets. From a pharmacologic point of view, these can be addressed by small chemical compounds, so-called biologicals (eg, mAbs and recombinant proteins), or by a rather new class of molecule based on the antisense concept. Recently, a new wave of clinical studies exploring antisense strategies is evolving. In addition to cancer, they include predominantly trials on infectious and noninfectious diseases, such as chronic inflammatory and metabolic conditions. This article, based on a systematic PubMed literature search, highlights recent developments in this emerging field. (J Allergy Clin Immunol 2016;137:1334-46.)
\end{abstract}

Key words: Clinical trial, antisense, small interfering RNA, DNAzyme, therapy

In recent years, we are observing the advent of novel therapeutic strategies in many disease areas. These strategies are primarily based on advancement in our understanding of disease mechanisms, resulting in identification of novel therapeutic targets. This includes chronic inflammatory diseases, such as allergies, asthma, chronic inflammatory bowel disease, rheumatoid arthritis, and other autoimmune disorders. Further examples are metabolic and cardiovascular diseases (CVDs), eye diseases, some neurologic disorders, and also infectious diseases, particularly in the field of viral infections. These developments go hand in hand with the ambitious strategy to provide novel individualized and personalized therapeutic approaches. From a pharmacologic point of view, the development of novel therapeutic strategies faces several major challenges: many targets are located intracellularly, thus requiring membrane

From the Institute of Laboratory Medicine, Philipps-University Marburg.

*These authors contributed equally to this work.

Supported by the PreDicta EC FP7 Collaborative Project (260895), Universities Giessen and Marburg Lung Centre (UGMLC), the German Centre for Lung Research (DZL; 82DZL00502), and the German Research Council (DFG; SFB1021, project C04).

Disclosure of potential conflict of interest: D. P. Potaczek, S. D. Unger, and H. Renz have received grants from PreDicta EC FP7 Collaborative Project (260895), Universities Giessen and Marburg Lung Centre (UGMLC), the German Centre for Lung Research (DZL; 82DZL00502), and the German Research Council (DFG; SFB1021, project C04). H. Garn has received grants from PreDicta EC FP7 Collaborative Project (260895), Universities Giessen and Marburg Lung Centre (UGMLC), the German Centre for Lung Research (DZL; 82DZL00502), and the German Research Council (DFG; SFB1021, project C04) and has consultant arrangements with and has received stock/stock options from Sterna Biologicals GmbH \& Co. KG.

Received for publication August 11, 2015; revised November 24, 2015; accepted for publication December 15, 2015.

Corresponding author: Harald Renz, MD, Institute of Laboratory Medicine, Philipps-University Marburg, Baldinger Straße, 35043 Marburg, Germany. E-mail: renzh@med.uni-marburg.de.

(Q) The CrossMark symbol notifies online readers when updates have been made to the article such as errata or minor corrections

0091-6749/\$36.00

(C) 2016 American Academy of Allergy, Asthma \& Immunology

http://dx.doi.org/10.1016/j.jaci.2015.12.1344

\section{Abbreviations used}

ALS: Amylotrophic lateral sclerosis

AMD: Age-related macular degeneration

CMV: Cytomegalovirus

CNV: Choroidal neovascularization

CVD: Cardiovascular disease

DMD: Duchenne muscular dystrophy

FDA: US Food and Drug Administration

HCV: Hepatitis $C$ virus

IRS-1: Insulin receptor substrate 1

LDL-C: Low-density lipoprotein cholesterol

MOE: 2'-O-methoxyethyl

ODN: Antisense oligodeoxyribonucleotide

PCSK9: Proprotein convertase subtilisin/kexin type 9

PT: Phosphorothioate

siRNA: Small interfering RNA

TLR: Toll-like receptor

VEGF: Vascular endothelial growth factor

passage of the drug molecules, and further challenges include the stability, systemic availability, and half-life of the compound and safety issues.

To address these challenges, several major avenues are being explored, including small (synthetic) molecules, mAbs, and antisense strategies. The antisense technology is primarily used to directly interfere with the machinery of the production of target proteins through inactivation of (m)RNA encoding for the target protein. This field has received great attention since the report of successful early-stage clinical studies, which have been performed in several disease areas, including allergy and asthma.

A variety of reviews appeared over the last years, focusing on the comparative description of different antisense approaches and the development of novel modifications of antisense molecules to overcome initial obstacles for their use as medicines. ${ }^{1-7}$ However, thus far, there is no comprehensive overview available summarizing the current status of the application of such compounds in clinical trials with some exception to the field of cancer. ${ }^{8,9}$

The aim of this review is to provide an update on this fascinating and rapidly developing field receiving increasing attention in the scientific and medical community. We will introduce the concept of the major antisense approaches, followed by an update on the clinical application of antisense molecules in the area of noncancer disorders.

\section{ANTISENSE STRATEGIES}

The term antisense molecules comprises several classes of oligonucleotide molecules that contain sequence complementarity to target RNA molecules, such as mRNA, viral RNA, or other RNA species, and that inhibit the function of their target RNA after sequence-specific binding. This goes back to its first 
TABLE I. General features of the main antisense molecule families

\begin{tabular}{|c|c|c|c|c|}
\hline & Antisense DNA (ODN) & siRNA & DNAzyme & RNAzyme \\
\hline $\begin{array}{l}\text { Oligo type and } \\
\text { structure }\end{array}$ & Linear ssDNA & Linear dsRNA & $\begin{array}{l}\text { ssDNA with } 2 \text { binding domains } \\
\text { surrounding a central catalytic } \\
\text { domain }\end{array}$ & $\begin{array}{l}\text { Complex RNA with single- } \\
\text { and double-strand sections }\end{array}$ \\
\hline Size & 12-25 bases & $21-25$ base pairs & $30-35$ bases & $\begin{array}{l}\text { - }>30 \text { bases (hammerhead } \\
\text { RNAzymes) } \\
\text { - }>50 \text { bases (hairpin } \\
\text { RNAzymes) }\end{array}$ \\
\hline $\begin{array}{l}\text { Inherent enzymatic } \\
\text { activity }\end{array}$ & No & No & Yes & Yes \\
\hline $\begin{array}{l}\text { Recruited enzymatic } \\
\text { activity }\end{array}$ & RNAses $\mathrm{H}, \mathrm{L}$, or $\mathrm{P}$ & RISC & $\mathrm{No}^{*}$ & No \\
\hline Modifications & $\begin{array}{l}\text { Multiple backbone } \\
\text { modifications established, } \\
\text { such as PT, 2-O-methyl, } \\
\text { 2-O-methoxyethyl, locked } \\
\text { nucleic acids }\end{array}$ & $\begin{array}{l}\text { Several modifications, } \\
\text { preferentially of terminal } \\
\text { nucleotide overhangs } \\
\text { established, such as } \\
3^{\prime} \text {-inverted thymidine }\end{array}$ & $\begin{array}{l}\text { 3'-Inverted thymidine to } \\
\text { enhance stability } \\
\text { Modifications in binding } \\
\text { arms possible }\end{array}$ & $\begin{array}{l}\text { Often unmodified (especially } \\
\text { when expressed in vivo), } \\
\text { several modifications } \\
\text { possible }\end{array}$ \\
\hline Advantages & $\begin{array}{l}\text { - Easy to produce, easy } \\
\text { to modify } \\
\text { - Good cell penetration, } \\
\text { especially for modified } \\
\text { short antisense DNAs }\end{array}$ & $\begin{array}{l}\text { - Can be generated } \\
\text { intracellularly from } \\
\text { larger precursors } \\
\text { by enzyme Dicer } \\
\text { - Degradation of whole } \\
\text { mRNA } \\
\text { - Multiple turnover }\end{array}$ & $\begin{array}{l}\text { Easy to produce } \\
\text { - Multiple potential cleavage } \\
\text { sites in target RNAs } \\
\text { - Good in vivo cell penetration } \\
\text { - No significant off-target effects } \\
\text { shown thus far } \\
\text { - Multiple turnover }\end{array}$ & $\begin{array}{l}\text { Multiple potential } \\
\text { cleavage sites in target } \\
\text { RNAs } \\
\text { - Can be expressed from } \\
\text { coding DNA sequences } \\
\text { in vivo }\end{array}$ \\
\hline Disadvantages & $\begin{array}{l}\text { - Off-target effects } \\
\text { - Potential protein-binding } \\
\text { (aptamer) activities } \\
\text { - Activity dependent on } \\
\text { intracellular enzymes }\end{array}$ & $\begin{array}{l}\text { - Off-target effects } \\
\text { - More difficult to produce } \\
\text { - Limited cell penetration } \\
\text { potential } \\
\text { - Activity dependent on } \\
\text { intracellular enzymes }\end{array}$ & $\begin{array}{l}\text { - Empiric selection process } \\
\text { - Activity depends on } \\
\text { intracellular } \mathrm{Mg}^{2+} \text { levels }\end{array}$ & $\begin{array}{l}\text { - Large size and complex } \\
\text { structure } \\
\text { - Empiric selection process } \\
\text { - Difficult to produce } \\
\text { - Limited in vivo stability }\end{array}$ \\
\hline
\end{tabular}

dsRNA, Double-stranded RNA; RISC, RNA-induced silencing complex; ssDNA, single-stranded DNA.

*Might also involve RNAses H, L, or P.

description in 1978, when the antiviral activity of antisense DNA molecules against the Rous sarcoma virus was shown. ${ }^{10,11}$ In the meantime, at least 4 major classes of antisense molecules have been described: antisense oligodeoxyribonucleotide (ODN), ie, single-stranded DNA molecules, small interfering RNA (siRNA) molecules, ribozymes, and DNAzymes (Table I). ${ }^{1}$

The by far most frequently used application of therapeutic antisense molecules is to reduce expression levels of proteins that have been associated with central mechanisms of disease development. In this regard antisense molecules bind to the mRNAs that have been generated by transcription from the genetic information in the nucleus. These mRNAs serve as coding molecules for the formation of respective proteins in a process called translation. Binding of antisense molecules can effectively inhibit this translational process because mRNAs associated with antisense molecules can no longer serve as matrices. Thus the expression level of intact mRNAs and, subsequently, their coded proteins can be reduced by effective antisense action (Fig 1). However, antisense strategies can also be developed to interfere with other functional aspects of RNA molecules, such as blocking of splicing, interference with appropriate folding, competing with protein binding to RNA sequences, antagonizing microRNA activities, and inhibiting RNA-mediated telomerase activity. ${ }^{2}$ Initially, it was thought that antisense molecules exert their activity through steric blocking of the target RNA with subsequent inhibition of RNA functionality. More detailed analyses of the mode of action of antisense molecules revealed that many of these structures involve enzymatic activities to fully exert their function
(Table I). In the case of RNAzyme and DNAzyme, this activity is inherent in the antisense molecule itself, as the names indicate, and thus these molecule families comprise enzymatically active oligonucleotides. ODNs can recruit intracellular enzymes, such as ribonucleases (RNAses) $\mathrm{H}$, L, or P, which cleave RNA on binding of the ODN molecule. siRNAs represent short RNA duplex molecules 21 to 25 bases long that involve the generation of the so-called RNA-induced silencing complex (RISC), which exerts ribonuclease activity with subsequent cleavage of the RNA target.

A variety of modifications were developed and applied to the different kinds of antisense molecules, mainly to increase their stability (Table I). Modifications should also enhance the bioavailability of these molecules, especially for therapeutic use, and improve binding to and inactivation of target RNAs. One of the first and still most widely applied modifications is the introduction of phosphorothioate (PT)-containing nucleotides to form a PT backbone in which oxygen atoms in the bridging structures are replaced by sulfur atoms (first-generation antisense drugs). This modification significantly increases the stability of antisense molecules in biological systems; however, it has been also associated with a variety of unwanted side effects. ${ }^{12}$ Other backbone modifications include phosphoramidate, methylphosphonate, phosphorodiamidate morpholino, or peptide nucleic acids.

More recent modifications (second- and third-generation antisense drugs) introduce changes into the heterocycle or (deoxy)ribose sugar to increase the stacking interaction with 


\section{A Health - balanced gene expression}

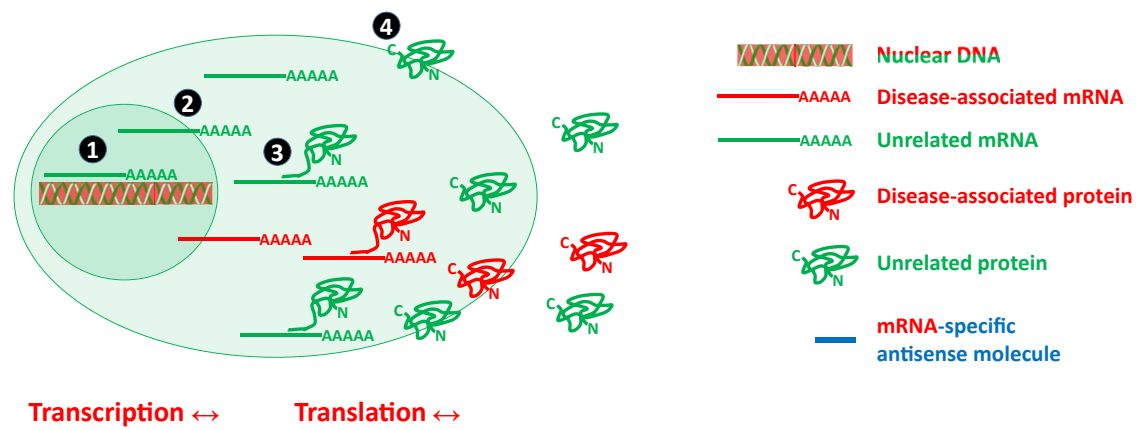

\section{B Pathology-associated with specific gene overexpression}

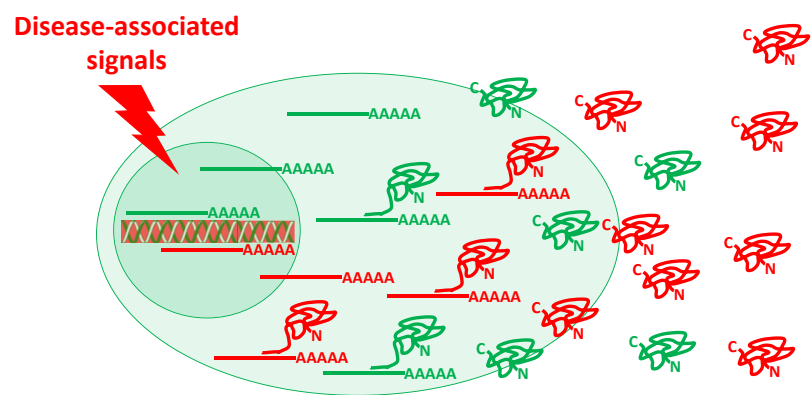

Transcription $\uparrow \quad$ Translation $\uparrow$

\section{Improved pathology under treatment with an antisense drug - neutralization of pathologic gene overexpression}

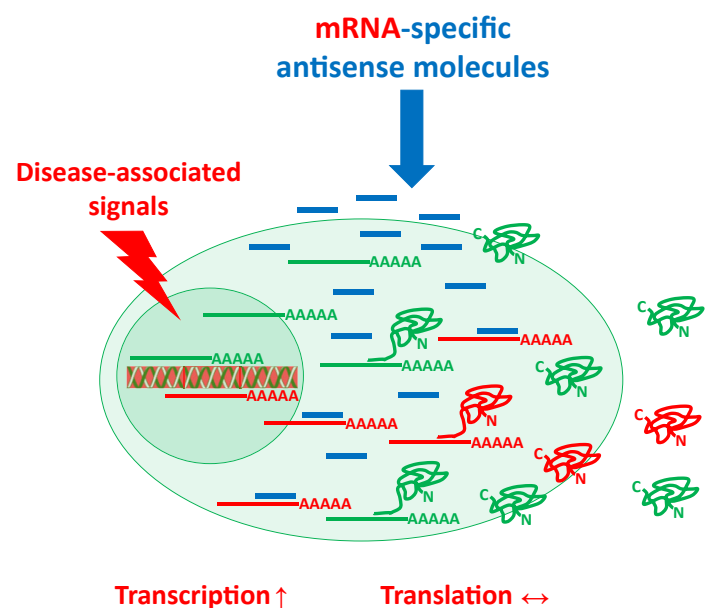

FIG 1. Mode of action of antisense molecules as inhibitors of disease-associated protein expression A, Under healthy conditions, cells permanently generate a variety of proteins needed for their own homeostasis and interaction with their environment in a tightly controlled process. Gene-specific mRNAs are transcribed from the respective DNA regions in the nucleus (1), and mRNAs are transferred to the cytoplasm (2). At the ribosomes, mRNA information is translated into the corresponding protein sequence (3). After appropriate processing, proteins are transported to their final location, which might be intracellular, membrane bound, or secreted to the extracellular space (4). B, Following disease-associated signals, the steady state of cells becomes disturbed, and transcription/translation of a variety of (disease-associated) genes/proteins can be significantly increased. This leads to a dysregulated cellular response, which drives the pathological process. C, Highly gene-specific antisense molecules can bind and subsequently block or even cleave targeted disease-associated mRNA molecules. This interaction inhibits translation into the respective protein and rebalances cellular activities toward normal conditions. 


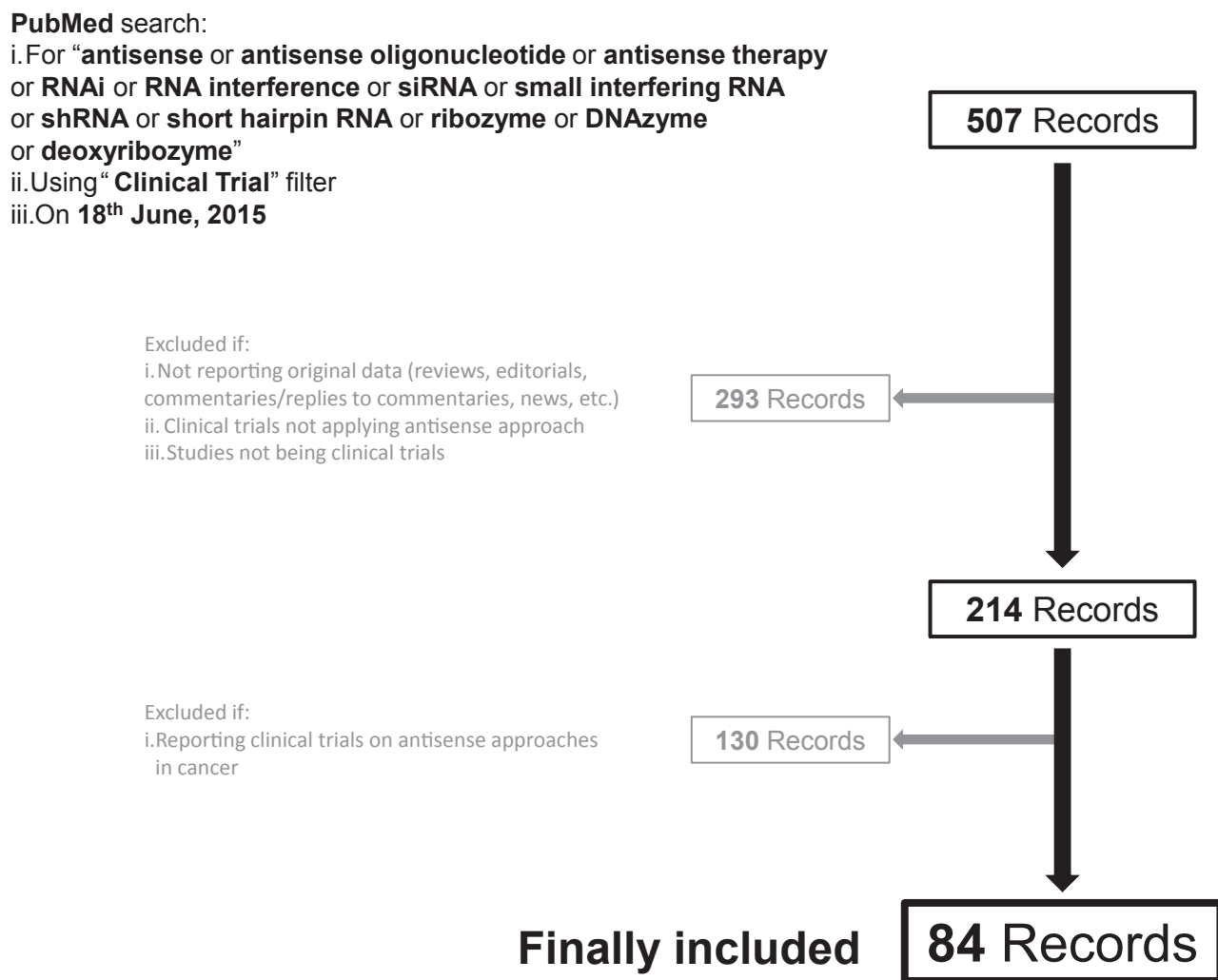

FIG 2. Strategy of the systematic literature search and its results.

the target molecule and nuclease resistance. Among the latter are 2'-O-methyl, 2'-O-methoxyethyl (MOE), and 2'-O-fluoro modifications. Most recently, so-called bicyclic and locked nucleic acids were developed that show significantly increased hybridization properties to target structures and high stability in biological fluids. ${ }^{3}$ However, most modifications are also associated with an altered toxicological profile requiring intense investigation of unwanted side effects for the respective antisense-based drug compound.

\section{SYSTEMATIC SEARCH}

To cover the area of interest, we conducted a systematic literature search. In brief, on June 18, 2015, the PubMed database (http://www.ncbi.nlm.nih.gov/pubmed) was searched by using the input "antisense OR antisense oligonucleotide OR antisense therapy OR RNAi OR RNA interference OR siRNA OR small interfering RNA OR shRNA OR short hairpin RNA OR ribozyme OR DNAzyme OR deoxyribozyme," restricting the results with the "Clinical Trial" filter, which yielded a total of 507 hits. These were subsequently subjected to abstract-based and, if necessary, full text-based screening to exclude further articles (1) not reporting original data (eg, reviews, editorials, commentaries/replies to commentaries, and news), (2) clinical trials not applying an antisense approach, and (3) studies that were not clinical trials, which resulted in elimination of 293 articles. From the remaining 214 articles, a further 130 papers describing the results of clinical trials on antisense-based treatment conducted in different types of cancer were also excluded (Fig 2). Cancer is an important area of antisense drug application; however, involvement of studies in this field would have expanded the article to an unmanageable size. The final 84 articles were then studied in detail and subgrouped based on the clinical area, the pathophysiologic character of addressed molecules, and/or the target of an antisense approach. The designs and major results of the trials reported in those 84 articles are briefly summarized in Table E1 in this article's Online Repository at www.jacionline.org. Subjectively selected studies are also discussed in the text and presented in Tables II-VI. ${ }^{13-65}$

\section{INFLAMMATORY DISORDERS}

Inflammatory diseases are multifactorial and complex disorders that require therapy with rather unspecific anti-inflammatory compounds (eg, corticosteroids and calcineurin inhibitors). For many reasons, there is need for more specific therapeutic approaches interfering with central molecules in crucial pathomechanistic pathways. These might represent molecules involved in the recruitment, activation, or both of inflammatory cells, such as molecules from cytokine/chemokine networks, receptors and signaling molecules, cell adhesion molecules, and transcription factors controlling the expression of sets of genes responsible for the development of certain disease conditions. Thus a variety of antisense approaches were developed over the last about 20 years that were intended to treat chronic inflammatory disease conditions in different organ systems (Table I and see Table E1).

One of the first antisense molecules applied in clinical studies was alicaforsen (ISIS 2302), a 20mer PT DNA molecule directed against the adhesion molecule intercellular adhesion molecule 1. Because intercellular adhesion molecule 1 is important for the recruitment of inflammatory cells, such as neutrophils, to the site 
TABLE II. Overall output of selected clinical trials on antisense drugs related to inflammatory disorders

\begin{tabular}{|c|c|c|c|c|}
\hline Target & $\begin{array}{l}\text { Antisense approach } \\
\text { (drug name) }\end{array}$ & $\begin{array}{c}\text { Disease (potentially) } \\
\text { targeted }\end{array}$ & General outcomes & References \\
\hline GATA-3 & DNAzyme (SB010) & Asthma & $\begin{array}{l}\text { Attenuation of late- and early-phase } \\
\text { asthmatic responses in allergen } \\
\text { provocation study after drug inhalation } \\
\text { Reduced systemic IL-5 levels } \\
\text { Good safety profile, low systemic exposure }\end{array}$ & $\begin{array}{l}\text { Homburg et al, } 2015^{23} \text {; } \\
\text { Krug et al, } 2015^{24}\end{array}$ \\
\hline $\begin{array}{l}\text { CCR3 and cytokine } \\
\text { common } \beta \text {-chain }\end{array}$ & $\begin{array}{l}\text { Combination of } 2 \\
\text { ODNs (TPI ASM8) }\end{array}$ & Asthma & $\begin{array}{l}\text { Reduction in allergen-induced early- and } \\
\text { late-phase asthmatic responses } \\
\text { Reduction in sputum eosinophil counts } \\
\text { Good safety profile }\end{array}$ & $\begin{array}{l}\text { Gauvreau et al, } 2008^{20} \\
\text { Gauvreau et al, } 2011^{21} \\
\text { Imaoka et al, } 2011^{22}\end{array}$ \\
\hline ICAM-1 & ODN (alicaforsen, ISIS 2302) & Crohn disease & $\begin{array}{l}\text { Some trends to higher frequency } \\
\text { of patients with remission, especially } \\
\text { in prespecified patients } \\
\text { Trends to reduced glucocorticoid } \\
\text { consumption } \\
\text { Postinfusion drug reactions, otherwise } \\
\text { well tolerated }\end{array}$ & $\begin{array}{l}\text { Yacyshyn et al, } 1998^{13} ; \\
\text { Yacyshyn et al, } 2002^{14} \text {; } \\
\text { Yacyshyn et al, } 2005^{15}\end{array}$ \\
\hline SMAD7 & ODN (GED0301) & Crohn disease & $\begin{array}{l}\text { Higher numbers of patients with clinical } \\
\text { remission } \\
\text { Reduced plasma levels of proinflammatory } \\
\text { mediators } \\
\text { Safe and well tolerated }\end{array}$ & $\begin{array}{l}\text { Monteleone et al, } 2012^{55} \text {; } \\
\text { Zorzi et al, } 2012^{56} ; \\
\text { Monteleone et al, } 2015^{19}\end{array}$ \\
\hline
\end{tabular}

ICAM-1, Intercellular adhesion molecule 1.

TABLE III. Overall output of selected clinical trials on antisense drugs related to viral infections

\begin{tabular}{|c|c|c|c|c|}
\hline Target & $\begin{array}{l}\text { Antisense approach } \\
\text { (drug name) }\end{array}$ & $\begin{array}{c}\text { Disease (potentially) } \\
\text { targeted }\end{array}$ & General outcomes & References \\
\hline miR-122 & ODN (miravirsen, SPC3649) & HCV infection & $\begin{array}{l}\text { Long-lasting reductions in plasma } \\
\text { HCV levels in patients with } \\
\text { chronic infection accompanied } \\
\text { by a good safety profile }\end{array}$ & Janssen et al, $2013^{28}$ \\
\hline $\begin{array}{l}\text { Major IE2 } \\
\text { protein-encoding } \\
\text { CMV mRNA }\end{array}$ & ODN (fomivirsen, Vitravene)* & $\begin{array}{l}\text { CMV retinitis } \\
\text { accompanying AIDS }\end{array}$ & $\begin{array}{l}\text { Effectiveness in patients with } \\
\text { newly diagnosed, relapsed, } \\
\text { or persistent retinitis based } \\
\text { on clinically assessed parameters } \\
\text { Well tolerated }\end{array}$ & $\begin{array}{l}\text { Vitravene Study Group, } 2002^{29} ; \\
\text { Vitravene Study Group, } 2002^{30} ; \\
\text { Vitravene Study Group, } 2002^{31}\end{array}$ \\
\hline $\begin{array}{l}\text { RSV nucleocapsid } \\
\mathrm{N} \text { protein mRNA }\end{array}$ & siRNA (ALN-RSV01) & RSV infection & $\begin{array}{l}\text { Lower rate of infection in } \\
\text { experimentally inoculated } \\
\text { healthy subjects and reduced } \\
\text { incidence of bronchiolitis } \\
\text { obliterans in lung transplant } \\
\text { recipients } \\
\text { Good safety profile }\end{array}$ & $\begin{array}{l}\text { DeVincenzo et al, } 2008^{32} \text {; } \\
\text { DeVincenzo et al, } 2010^{33} \text {; } \\
\text { Zamora et al, } 2011^{34}\end{array}$ \\
\hline $\begin{array}{l}\text { Overlapping vpr } \\
\text { and tat genes } \\
\text { of HIV-1 RNA }\end{array}$ & $\begin{array}{l}\text { Gammaretroviral vector } \\
\text { expressing hammerhead } \\
\text { ribozyme delivered within } \\
\text { transduced cells (RRz2, OZ1) }\end{array}$ & HIV-1 infection & $\begin{array}{l}\text { Long-term engraftment of } \\
\text { transduced cells } \\
\text { Reduction in some measures of } \\
\text { viral load in HIV-1-infected } \\
\text { patients } \\
\text { Procedure feasible and well } \\
\text { tolerated }\end{array}$ & $\begin{array}{l}\text { Amado et al, } 2004^{25} ; \\
\text { MacPherson et al, } 2005^{26} \text {; } \\
\text { Mitsuyasu et al, } 2009^{27}\end{array}$ \\
\hline
\end{tabular}

$C M V$, Cytomegalovirus; $I E 2$, immediate-early region $2 ; R S V$, respiratory syncytial virus.

*Approved by the FDA for local treatment of CMV retinitis in patients with AIDS who are intolerant or have a contraindication to other treatments for CMV retinitis or who were insufficiently responsive to previous treatments for CMV retinitis. ${ }^{80}$ 
TABLE IV. Overall output of selected clinical trials on antisense drugs related to metabolic diseases

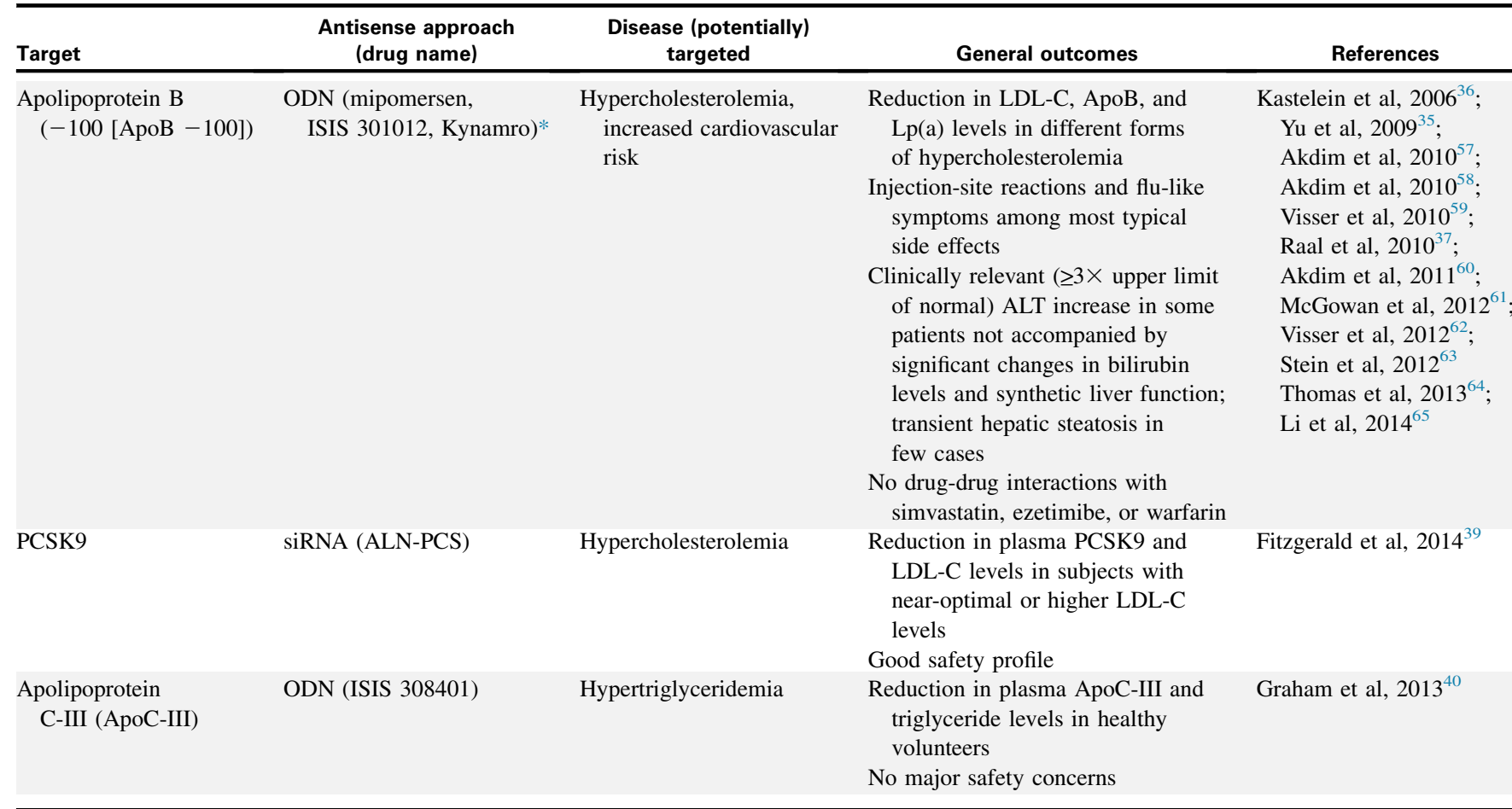

$A L T$, Alanine transaminase; $L p(a)$, lipoprotein(a).

*Approved by the FDA as complementary treatment of patients with homozygous familial hypercholesterolemia. ${ }^{38}$

of inflammation, this molecule is overexpressed in a variety of inflammatory disease conditions, including chronic inflammatory intestinal disorders. In fact, after phase I safety studies ${ }^{66}$ demonstrating a favorable safety profile, alicaforsen was first applied in patients with Crohn disease in a variety of trials. Although systemic application through intravenous infusion did not significantly improve the rate of remissions, several studies described positive effects on reduction of glucocorticoid consumption, ${ }^{13,67}$ Crohn disease activity index, and/or inflammatory bowel disease score. ${ }^{14}$ Later studies demonstrated a significant correlation with remission in a subpopulation of patients carrying single nucleotide polymorphisms in the gene encoding TNF- $\alpha^{15}$; however, no significant clinical response was observed in relation to previous use of anti-TNF- $\alpha$ antibody therapy. ${ }^{68}$ Rectal formulation of the same antisense drug through an enema was applied for the treatment of ulcerative colitis and chronic pouchitis in several studies, resulting in dose-dependent improvement of disease activity index ${ }^{16,69}$ and prolonged durability of treatment effects compared with mesalazine standard therapy. ${ }^{17,18}$ Systemic application of alicaforsen in patients with rheumatoid arthritis ${ }^{70}$ and renal allograft rejection ${ }^{71}$ did not result in significant treatment effects.

Regarding Crohn disease, a new approach was recently developed based on an antisense DNA molecule against the transcription factor SMAD7. SMAD7 acts as an inhibitor of the immunosuppressive cytokine TGF- $\beta 1$ signaling cascade and has been shown to be upregulated in the colons of patients with Crohn disease. Interestingly, the SMAD7-specific antisense drug mongersen is applied orally by using a polymer-coated tablet. Treatment with this compound was demonstrated to be safe and well tolerated, and a recently finished phase IIa study revealed significantly higher numbers of patients with clinical remission at day 15 and maintenance of remission for at least 2 weeks in the 2 higher-dose groups (40 or $160 \mathrm{mg} / \mathrm{d}$, respectively) compared with placebo. $^{19}$

A combination of 2 antisense DNA molecules called TPI ASM8 was developed and investigated in a series of 3 clinical studies for the treatment of allergic asthma. Although one component of this drug is directed against the chemokine receptor CCR3, which is crucially involved in the attraction of eosinophils, mast cells, and basophils to the site of inflammation, the other antisense molecule corresponds to the mRNA of the cytokine receptor common $\beta$-chain, which is an essential part of IL-3, IL-5, and GM-CSF receptors, all of which are involved in the generation and recruitment of eosinophils. The inhaled application of TPI ASM8 showed a favorable safety profile. $^{20}$ Furthermore, in allergen provocation studies a significant reduction in asthmatic early- and late-phase responses was observed and paralleled by an improvement in airway hyperresponsiveness and reduction in sputum eosinophil numbers and target gene expression. ${ }^{21,22}$

Most recently, a DNAzyme-based drug was successfully applied in a clinical study for the first time. SB010 represents a DNAzyme directed against GATA-3, the master transcription factor of $\mathrm{T}_{\mathrm{H}}$ 2-driven immune responses. GATA-3 is mainly expressed in $\mathrm{T}_{\mathrm{H}} 2$ cells themselves, where it controls expression of the $\mathrm{T}_{\mathrm{H}} 2$ subtype-specific cytokines IL-4, IL-5, and IL-13 and is thus crucially involved in the differentiation and activation of this specific T-cell subtype. Moreover, GATA-3 is also expressed in effector cells of allergic inflammatory responses, such as eosinophils, mast cells, basophils, and (bronchial) epithelial cells, and thus represents an interesting target for an antisense-based treatment strategy for $\mathrm{T}_{\mathrm{H}} 2$-driven allergic inflammatory disease conditions, such as allergic asthma. In fact, inhaled application 
TABLE V. Overall output of selected clinical trials on antisense drugs related to ocular diseases

\begin{tabular}{|c|c|c|c|c|}
\hline Target & $\begin{array}{l}\text { Antisense approach } \\
\text { (drug name) }\end{array}$ & Disease (potentially) targeted & General outcomes & References \\
\hline RTP801 & siRNA (PF-04523655) & $\begin{array}{l}\text { Neovascular AMD, } \\
\text { diabetic macular edema }\end{array}$ & $\begin{array}{l}\text { Improvement in visual acuity } \\
\text { vs comparator alone in subjects } \\
\text { with neovascular AMD or diabetic } \\
\text { macular edema } \\
\text { Generally safe and well tolerated }\end{array}$ & $\begin{array}{l}\text { Nguyen et al, } 2012^{41} ; \\
\text { Nguyen et al, } 2012^{42} ; \\
\text { Nguyen et al, } 2012^{43}\end{array}$ \\
\hline $\begin{array}{l}\text { Insulin receptor } \\
\text { substrate-1 (IRS1) }\end{array}$ & ODN (aganirsen, GS-101) & $\begin{array}{l}\text { Progressive corneal } \\
\text { neovascularization } \\
\text { secondary to keratitis } \\
\text { or keratouveitis }\end{array}$ & $\begin{array}{l}\text { Beneficiary effects on corneal } \\
\text { neovascularization, such as } \\
\text { inhibition, reduction/regression, } \\
\text { and/or stabilization } \\
\text { Generally safe and well tolerated }\end{array}$ & $\begin{array}{l}\text { Kain et al, } 2009^{44} \\
\text { Cursiefen et al, } 2009^{45} \\
\text { Cursiefen et al, } 2014^{46}\end{array}$ \\
\hline $\begin{array}{l}\beta_{2} \text {-Adrenergic } \\
\text { receptor (ADRB2) }\end{array}$ & siRNA (SYL040012) & Glaucoma & $\begin{array}{l}\text { Reduction of IOP in healthy subjects } \\
\text { with higher baseline IOP values } \\
\text { Safe and well tolerated }\end{array}$ & $\begin{array}{l}\text { Moreno-Montańés } \\
\text { et al, } 2014^{47}\end{array}$ \\
\hline $\begin{array}{l}\text { Gap junction protein, } \\
\text { alpha } 1 \text { (connexin } 43)\end{array}$ & ODN (Cx43AsODN) & $\begin{array}{l}\text { Persistent severe ocular } \\
\text { burns }\end{array}$ & $\begin{array}{l}\text { Rapid reduction of inflammation } \\
\text { in subjects with persistent severe } \\
\text { chemical and/or thermal ocular } \\
\text { burns unresponsive to established } \\
\text { therapy } \\
\text { Complete and stable corneal } \\
\text { re-epithelialization }\end{array}$ & Ormonde et al, $2012^{48}$ \\
\hline
\end{tabular}

IOP, Intraocular pressure.

TABLE VI. Overall output of selected clinical trials on antisense drugs related to diseases not covered by the previous sections ("miscellaneous")

\begin{tabular}{|c|c|c|c|c|}
\hline Target & $\begin{array}{c}\text { Antisense approach } \\
\text { (drug name) }\end{array}$ & $\begin{array}{l}\text { Disease (potentially) } \\
\text { targeted }\end{array}$ & General outcomes & References \\
\hline $\begin{array}{l}\text { Dystrophin gene mutant } \\
\text { mRNA with premature } \\
\text { stop codon }\end{array}$ & $\begin{array}{l}\text { RNA (PRO051, drisapersen, } \\
\text { GSK2402968) }\end{array}$ & DMD & $\begin{array}{l}\text { Reintroduction of open reading frame } \\
\text { with production of quasinormal } \\
\text { protein and performance improvement } \\
\text { in patients } \\
\text { Good safety profile }\end{array}$ & $\begin{array}{l}\text { Van Deutekom et al, } 2007^{50} ; \\
\text { Goemans et al, } 2011^{51} ; \\
\text { Voit et al, } 2014^{52}\end{array}$ \\
\hline $\begin{array}{l}\text { Integrin, } \alpha 4 \text { (CD49D, } \\
\alpha \text { subunit of VLA-4 } \\
\text { receptor) }\end{array}$ & ODN (ATL1102) & MS & $\begin{array}{l}\text { Reduced disease activity in patients with } \\
\text { relapsing-remitting MS } \\
\text { Fairly good safety profile }\end{array}$ & Limmroth et al, $2014^{53}$ \\
\hline Coagulation factor XI & ODN (ISIS 416858) & VTE & $\begin{array}{l}\text { Lower incidence of VTE in patients } \\
\text { undergoing knee arthroplasty compared } \\
\text { with standard protection } \\
\text { Good safety profile }\end{array}$ & Büller et al, $2015^{54}$ \\
\hline Transthyretin & $\begin{array}{l}\text { siRNA (ALN-TTR01 and } \\
\text { ALN-TTR02*) }\end{array}$ & $\begin{array}{l}\text { Transthyretin } \\
\text { amyloidosis }\end{array}$ & $\begin{array}{l}\text { Rapid and durable decrease in mutant } \\
\text { and wild-type transthyretin levels } \\
\text { in patients and healthy subjects } \\
\text { Fairly good safety profile }\end{array}$ & Coelho et al, $2013^{49}$ \\
\hline
\end{tabular}

$M S$, Multiple sclerosis; $V L A-4$, very late antigen 4; VTE, venous thromboembolism.

*Representing 2 formulations of the same siRNA.

of SB010 was demonstrated in a series of 3 phase 1 studies in healthy and asthmatic subjects to be safe and well tolerated. ${ }^{23}$ A subsequent phase IIa study provided evidence for significant improvement of early- and late-phase asthmatic responses to an allergen challenge after treatment with the GATA-3-specific DNAzyme-based drug, as demonstrated by significantly attenuated area under the curve for $\mathrm{FEV}_{1}$. These clinical improvements were associated with a marked attenuation of allergen-induced sputum eosinophilia and lower sputum tryptase and serum IL-5 levels. ${ }^{24}$ The latter studies are promising examples of the potential of antisense-based drugs as locally applied treatment options with high therapeutic efficacy and limited (systemic) side effects.

\section{VIRAL INFECTIONS}

In general, viral infections are addressed either symptomatically (eg, common colds) or indirectly (eg, stimulation of antiviral response by interferons). Until quite recently, drugs specifically inhibiting viral replication had not been broadly available. This situation started to change in the last 2 to 3 decades, with substantial progress made in the development of more specific therapeutics against hepatitis viruses, influenza, and especially HIV. Nevertheless, there is still much room for improvement, which could be filled by an application of antisense strategies. By their nature, antisense drugs can also offer much better (antiviral) specificity. 
In comparison with other antisense strategies described in this review, those against viruses are characterized by substantially higher methodological complexity and heterogeneity, resulting mostly from virus-to-virus differences in the structure of genomic material (single- or double-stranded DNA or RNA, positive- or negative-sense single-stranded RNA, and reverse transcriptase) and thus expression and/or replication biology. On the other hand, additional RNA types, eg, negative sense RNA synthesized during replication of the genome of single-stranded positive sense RNA viruses, transiently appearing within the lifecycle of some viral pathogens increase the number of potential targets for antisense (anti-RNA) therapy.

The most interesting, although complex, approach has been recently tested in the case of HIV with the aim of not only controlling the infection but potentially curing the host as well (Table III and see Table E1). ${ }^{25-27,72,73}$ In principal, CD4 ${ }^{+} \mathrm{T}$ cells or $\mathrm{CD} 34^{+}$progenitor cells were harvested, ex vivo transduced and re-expanded, and then reinfused. Vectors used for transduction encoded antisense molecules, such as ribozyme, short hairpin RNA, and/or long antisense RNA, the sustained expression of which was present even a few years after engraftment of the transduced cells. In all studies the procedure was safe, without any adverse effects different from those typical for autologous cell transplantation. Finally, the results of the 2 studies analyzing direct and/or indirect antiviral efficacy of this approach were at least partly promising. ${ }^{27,73}$ Although further improvements and optimizations are probably required, the strategy based on transduction of autologous cells with anti-HIV moleculeexpressing vectors seems to create a chance of developing a therapy bringing long-term or even curative effects. Achieving these goals would be possibly much more difficult with current antiviral drugs or simpler HIV-targeting antisense approaches. $^{74,75}$

The strategy involving a plasmid expressing antiviral antisense molecules has also been used in the case of hepatitis B virus against which a vector encoding 4 different short hairpin RNAs (NUC B1000) has been developed. Although shown to be safe after intravenous infusion, it has not been yet tested for its antiviral efficacy. ${ }^{76}$ Also, hepatitis $\mathrm{C}$ virus (HCV) became a target of antisense approaches. Although the PT ODN directly binding to HCV genomic RNA (ISIS 14803) did not prove to be strikingly effective, ${ }^{77,78}$ a very promising result has been reported for a locked nucleic acid PT ODN targeting microRNA-122 (miravirsen, SPC3649), a human-encoded molecule required for an effective HCV propagation (Table III and see Table E1). ${ }^{28,79}$ It is possible that such an indirect variant of antisense strategy could be a good solution in case of some viruses, especially those in which genomic material cannot be effectively approached because of its strong folding.

In addition to those applied systemically, topically administered antiviral antisense drugs, such as those against cytomegalovirus (CMV) retinitis (fomivirsen [Vitravene]; Novartis, Basel, Switzerland), ${ }^{29-31}$ or respiratory syncytial virus (RSV) infection/ bronchiolitis (ALN-RSV01), ${ }^{32-34}$ have been clinically studied, with very favorable results (Table III and see Table E1). Intravitreally injected fomivirsen, a PT ODN targeting CMV mRNA encoding major immediate-early region 2 proteins, was shown to be effective and well-tolerated in patients with AIDS and newly diagnosed, relapsed, or persistent CMV retinitis in phase III trials. In 1998 and as a first antisense molecule, it received US Food and Drug Administration (FDA) approval for the local treatment of CMV retinitis in patients with AIDS who are intolerant or have a contraindication to other treatments for CMV retinitis or who were insufficiently responsive to previous treatments for CMV retinitis. ${ }^{80}$ Successful in terms of both safety and efficiency, data obtained for ALN-RSV01, a multiply modified siRNA against RSV mRNA encoding the nucleocapsid $\mathrm{N}$ protein delivered as a either nasal spray or nebulization, suggest in turn that also other viruses infecting the upper and/or lower respiratory tract, eg, influenza or human rhinoviruses, could eventually be targeted with antisense approaches.

\section{METABOLIC DISEASES}

Atherosclerosis is a thickening of the arterial wall resulting from an accumulation of white blood cells, especially macrophages, absorbing oxidized low-density lipoprotein cholesterol (LDL-C) to form so-called "fatty streaks," a crucial step in the development of atherosclerotic plaque. These changes have 2 major consequences: (1) narrowing of the arterial lumen results in blood flow limitation and chronic ischemia in the supplied organs and (2) atherosclerotic plaques tend to become unstable and vulnerable, which can lead to plaque erosion and rupture, with subsequent thrombosis suddenly closing the artery, followed potentially by acute infarction. These 2 processes lead to the chronic or acute symptoms of CVD, respectively, with the clinical picture depending on the arterial bed. ${ }^{81-84}$ Thus, not surprisingly, dyslipidemia, especially hypercholesterolemia, is one of the major risk factors of atherosclerotic changes leading to the development of CVD. ${ }^{85,86}$ Apolipoprotein B-100 (ApoB-100) is an essential structural and receptor-binding component of all atherogenic lipoproteins, including LDL and its metabolic precursors. Hence specific targeting of ApoB-100 by means of antisense strategies should make it possible to reduce LDL-C levels and therefore the risk of $\mathrm{CVD}{ }^{87,88}$ Indeed, an MOE-modified PT ODN against ApoB-100 (ISIS 301012, mipomersen [Kynamro]; Genzyme, Cambridge, Mass) has been developed and widely tested in clinical trials (Table IV and see Table E1). After initial studies showed neither relevant drug-drug interactions nor inhibition of major CYP enzymes ${ }^{35}$ and provided acceptable safety results, ${ }^{36}$ several subsequent efficacy trials have been conducted in populations with different forms of dyslipidemia, varying in terms of severity, pathogenesis (several studies on heterozygous or homozygous familial hypercholesterolemia), accompanying disorders or susceptibility to them (coronary artery disease and increased CVD risk), and/or response to standard lipid-decreasing treatment (stable therapy or maximally tolerated doses). Together, they have shown a significant (and dose-dependent) reduction in circulating LDL-C, ApoB, and, where investigated, lipoprotein (a) levels in subjects treated with subcutaneous mipomersen. ${ }^{36,37,57-64}$ Of note, those trials included not only phase II but also phase III clinical studies, in which collectively almost 400 subjects were randomized 2:1 to weekly receive $200 \mathrm{mg}$ of mipomersen or placebo for 26 weeks. $^{37,61,63,64,89}$ Treatment with mipomersen is associated with some side effects, including increases in liver enzyme levels (although without significant changes in bilirubin levels and synthetic liver function), (transient) hepatic steatosis, and flu-like symptoms. The mechanistic reasons for these adverse effects have not been fully elucidated. Established lipiddecreasing therapy with statins makes it possible to control cholesterol levels in the majority of patients. In some subjects 
at high CVD risk with marked hypercholesterolemia, such as those with familial hypercholesterolemia, however, standard medications are not capable of adequately reducing LDL-C levels despite maximally tolerated doses, thus making a space for mipomersen and possibly other antisense approach-based hypolipidemic drugs. ${ }^{85,87,88}$ Successful clinical trials of mipomersen have already resulted in its approval by the FDA as complementary treatment of patients with homozygous familial hypercholesterolemia. $^{38}$

Proprotein convertase subtilisin/kexin type 9 (PCSK9), the enzyme whose binding to LDL receptors leads to their degradation, represents another potential antisense target involved in LDL-C biology. Recently, a multiply modified, lipid nanoparticle-encapsulated siRNA against PCSK9 (ALN-PCS) has demonstrated a good safety profile and efficiency in reducing PSCK9 plasma protein and LDL-C levels on intravenous infusion in healthy subjects with near-optimal or higher LDL-C levels. ${ }^{39}$ Apolipoprotein C-III (ApoC-III), an independent risk factor and key regulator of plasma triglyceride levels, has been addressed by an antisense strategy as well. Subcutaneously injected MOE-modified PT ODN (ISIS 308401) has not only been proved safe but also demonstrated to reduce plasma ApoC-III and triglyceride concentrations in healthy subjects. ${ }^{40}$ The results of the latter 2 studies are very promising, but we need to wait for phase II trials data to determine whether the substances they tested will repeat the success of mipomersen.

\section{OCULAR DISEASES}

Age-related macular degeneration (AMD) is the leading cause of irreversible blindness in the developed world. Choroidal neovascularization $(\mathrm{CNV})$, the hallmark of the neovascular form of $\mathrm{AMD}$, is responsible for most cases of severe vision loss resulting from AMD. ${ }^{90-92}$ After the discovery of vascular endothelial growth factor (VEGF) as a key stimulatory factor in angiogenesis, it became a promising target for novel treatment modalities of CNV caused by neovascular AMD. Indeed, anti-VEGF therapies have demonstrated a potential to inhibit disease progression and improve vison. ${ }^{90-93}$ Antisense strategies have been also directed at $\mathrm{CNV}$ caused by AMD by mean of direct targeting of the VEGF pathway, specifically VEGF receptor 1 . In patients with this condition, intravitreally injected anti-VEGFR-1 siRNA (Sirna-027, AGN 211745) has been shown to be well tolerated and to stabilize or improve visual acuity and foveal thickness. ${ }^{94}$ However, to make further progress in the development of neovascular AMD treatment, it could be beneficial to address aspects of the disease other than angiogenesis. This might include strategies to protect neurons from hypoxia, oxidative stress, or both. One of the proteins upregulated by the latter 2 conditions is RTP801, overexpression of which can lead to neuronal damage. ${ }^{95,96}$ An MOE-modified siRNA targeting RTP801 (PF-04523655) has been developed and subsequently tested in clinical trials (Table $\mathrm{V}$ and see Table E1). ${ }^{41,42}$ It has been demonstrated to be safe and well tolerated on intravitreal injection. Furthermore, a higher average gain in visual acuity was observed in patients with subfoveal $\mathrm{CNV}$ caused by neovascular AMD treated with the combination of PF-04523655 and ranibizumab (an mAb neutralizing VEGF) when compared with ranibizumab alone. This observation might reflect the independence and potential complementarity of the mechanisms of action between the 2 drugs. However, one cannot exclude that the beneficiary effects of PF-04523655 are partly mediated by its influence on VEGF expression through the m-TOR pathway. ${ }^{42}$ In addition, PF-04523655 has been tested in patients with diabetic macular edema, demonstrating improvement in visual acuity in this group. ${ }^{43}$

Antisense approaches addressed neovascularization in the cornea as well. Aganirsen (GS-101), a PT ODN-targeting insulin receptor substrate 1 (IRS-1) delivered as eye drops, has been shown to be safe and well tolerated ${ }^{44}$ and to exert beneficial effects, such as inhibition, reduction/regression, and/or stabilization, on progressive corneal neovascularization secondary to keratitis or keratouveitis. ${ }^{45,46}$ These were accompanied by a lower corneal transplantation need and improved quality of life observed in a recent phase III clinical trial (Table $\mathrm{V}$ and Table E1). ${ }^{46}$ IRS-1 is a cytoplasmic docking protein that mediates downstream signaling of insulin and insulin-like growth factor 1 . The insulin-like growth factor 1 system is thought to be involved in angiogenesis, possibly through regulation of VEGF or other cytokines. $^{97,98}$ In preclinical studies antiangiogenic effects of IRS-1 knockdown with aganirsen were indeed accompanied by decreased expression of IL-1 $\beta$, VEGF, or both. ${ }^{99,100}$ Interestingly, formulated as a skin ointment and applied in patients with plaque psoriasis, aganirsen led a to reduced lesion size, diminished expression of IRS-1 and VEGF, and a decrease in T-cell infiltration and keratinocyte proliferation (see Table E1). ${ }^{101}$

Also, other ocular conditions have been targeted by antisense approaches. Eye drops containing SYL040012, an siRNA against the $\beta_{2}$-adrenergic receptor (ADRB2), were found to be safe and well tolerated and to reduce intraocular pressure in healthy volunteers, and thus they can be expected to be further tested in patients with glaucoma. ${ }^{47}$ Targeting connexin 43 with the topical gel-formulated ODN Cx43AsODN in subjects with persistent severe chemical and/or thermal ocular burns unresponsive to established therapy led to a rapid reduction in inflammation, as well as a complete and stable corneal re-epithelialization (Table V and see Table E1). ${ }^{48}$ Taken together, along with the trials on CMV retinitis discussed above, ${ }^{29-31}$ these studies indicate that the eye represents another important organ with diseases accessible to local therapy with antisense strategies.

\section{MISCELLANEOUS}

In other disease areas important clinical trials have also been conducted recently (Table VI and Table E1). The antisense approaches studied there included simple or modified RNA/ DNA oligonucleotides, siRNA, or a ribozyme, and with the exception of the trial on transthyretin amyloidosis, in which lipid nanoparticle encapsulation was applied, they were delivered to the patients as naked molecules.

Familial amylotrophic lateral sclerosis (ALS), ${ }^{102}$ transthyretin amyloidosis, ${ }^{49}$ pachyonychia congenita, ${ }^{103}$ and Duchenne muscular dystrophy (DMD) ${ }^{50-52}$ all have a genetic background. In the case of DMD, antisense treatment aims to restore dystrophin-encoding target gene expression by means of correction of detrimental effects of the mutations on mRNA splicing, leading to formation of an internal (premature) stop codon. This is achieved by affecting splicing in a way that reintroduces an open reading frame, enabling production of a quasinormal (internally truncated) protein, and thus the course of the disease can be alleviated. ${ }^{104}$ In patients with ALS, transthyretin amyloidosis, or pachyonychia congenita, in turn, 
the biochemical goal of the therapy is to (selectively) reduce the undesired expression of (mutant) mRNA, specifically superoxide dismutase 1, soluble; transthyretin; or keratin 6A, type II transcripts. ${ }^{4,102,105,106}$ Also, in patients with myasthenia gravis, the antisense treatment targets a genetically undetermined, so-called read-through unwanted splicing variant of acetylcholinesterase mRNA, overproduction of which contributes to the pathophysiology of the disease. Interestingly, this last molecule was also found to act as a Toll-like receptor (TLR) 9 ligand, which seems to further boost its primary antisense effect. ${ }^{107-110}$ Differing by means of administration, ranging from oral through subcutaneous, intravenous, intramuscular, and intrathecal to intradermal, the antisense molecules against DMD (PRO051, drisapersen, GSK2402968), myasthenia gravis (EN101, monarsen), ALS (ISIS 333611), transthyretin amyloidosis (ALN-TTR01/ALN-TTR02), and pachyonychia congenital (TD101) all produced no serious adverse effects, showed a good safety profile, and, except for a molecule against ALS not yet tested for this kind of effect, demonstrated promising biochemical and/or clinical results in terms of efficacy. This creates a chance for some other disorders, the pathology of which is based on (mutation-determined) gene overexpression. However, an application of the antisense strategy successfully used for DMD might be more difficult in case of some other genetically determined deficiencies in protein synthesis resulting from introduction of the premature stop codon, eg, Marfan syndrome or natural anticoagulation defects. ${ }^{111-113}$ This is because in these or similar conditions, restoration of fully and not only partially functional protein expression might be more crucial. While discussing the application of antisense approaches in patients with neuromuscular or neurologic disorders, such as ALS or myasthenia gravis, a very recent trial was conducted in patients with relapsing-remitting multiple sclerosis. A modified ODN ATL1102 targeting integrin, the alpha 4 gene (also known as CD49D or the alpha subunit of the very late antigen 4 receptor), was tested. The results of this study showed very promising results in terms of multiple sclerosis activity reduction and general good tolerance of the treatment. ${ }^{53}$

Although multiple novel modalities of venous thromboembolism prevention have been developed lately, the risk of iatrogenic hemorrhage remains a concern with anticoagulation therapy, ${ }^{84,114}$ thus making a space for a new ODN targeting coagulation Factor XI (ISIS 416858) that proved to be both clinically effective and safe with regard to uncontrolled bleeding. ${ }^{54}$ Not only venous system but also arterial bed disorders, specifically coronary arteries affected by atherosclerosis, have been addressed recently by using antisense therapy. Two independent antisense molecules against c-myc mRNA synthesized from the overlapping region of the gene demonstrated a good safety profile on intracoronary delivery in patients with coronary artery disease, although one of them produced no clear clinical benefits in terms of unfavorable remodeling and restenosis after stent implantation. ${ }^{115-117}$

\section{CURRENT CONSIDERATIONS AND FUTURE PERSPECTIVES}

Two antisense drugs have been approved by the FDA thus far, fomivirsen (in 1998) and mipomersen (in 2013), ${ }^{38,80}$ and the number of clinical studies on this group of medications has increased over the last 5 to 10 years. Analyzing publication dates of clinical trial papers on antisense drugs, as summarized in Table E1, makes it clear that more than $75 \%$ of them were published after 2005 (inclusive) and more than half after 2010 (inclusive). Also, the success of mipomersen seems to be a result of those 2 waves, especially the latter. Considering the increasing number of published clinical studies (and most probably those ongoing as well), one could possibly expect that further antisense drugs will soon become available on the market.

There are several reasons for this optimism. The last few years yielded a variety of modifications in the chemistry of antisense drugs, resulting in improved binding affinity and stability. ${ }^{6,7}$ On the other hand, the more modified antisense drugs become, the less natural the products of their degradation might be, which was one of their original advantages over chemical compounds. Furthermore, many studies reported successful application of locally administered antisense therapy accompanied by an advantageous systemic pharmacokinetic profile (ie, limited appearance and rapid clearance of drugs from circulation). From this point of view, it would not be necessary to increase the stability of locally administered antisense drugs over a certain limit, especially because their regional effect can be sustained by more frequent application. Naturally, enhanced stability and a lasting presence in the circulating blood would be beneficial for drugs administered systemically. However, some of those drugs can induce adverse effects, such as liver steatosis and flu-like symptoms in the case of mipomersen. Indeed, side effects, especially liver-related effects, were the most important reason for lack of European Medicines Agency approval for mipomersen. ${ }^{118}$

In general, adverse effects of antisense drugs can be grouped based on (1) route of delivery an place of action (local effects, eg, local injection-site reactions, ocular surface discomfort after administration of eye drops, and itching after application of skin ointment, or systemic effects, eg, flu-like symptoms, liver toxicity, or prolongation of activated partial thromboplastin time); (2) type of carrier; and (3) character of the antisense molecule itself (off-target effects through silencing of additional genes or modulation of other targets, eg, TLRs, resulting from biochemistry of the molecule $\mathrm{e}^{4,6,7}$ ). Intriguingly, in some cases the effect mediated through TLRs can enhance the primary gene-silencing action of the antisense drug. ${ }^{110}$

Delivery of antisense molecules represents another important issue. They are thought to be primarily taken up by cells through endocytosis. ${ }^{119}$ Interestingly, in all clinical trials analyzing the effects of locally delivered (inhalation by means of oral nebulization, nasal spray, skin ointment, enema, intravitreal injection, and many others) antisense drugs and a huge majority of studies investigating those administered systemically (eg, intravenous infusion, oral tablets, and subcutaneous injection), as identified by our search, including those successful in term of therapeutic efficacy, candidate molecules are administered in the form of naked compounds (see Table E1). Because ex vivo uptake of antisense molecules typically requires additional effort, such as use of transfection reagents, one might speculate that some specific and/or unspecific mechanisms supporting their cellular uptake exist in vivo. Still, to (further) improve the delivery of antisense compounds, especially those administered systemically, additional techniques are being applied, eg, lipid nanoparticle encapsulation or covalent linking to molecules potentially offering additional benefit of targeting specific cells, tissues, or organs. ${ }^{5,39,49}$ In addition, a strategy of harvesting human cells, their ex vivo retroviral or lentiviral transduction 
with vectors expressing antisense molecules, and subsequent reinfusion, potentially guaranteeing long-term silencing effects, has been developed for use in patients with HIV. ${ }^{25-27,72,73}$

Taken together, promising efficacy results and reasonable tolerance, the latter especially evident in case of local therapies, open the perspective to increase the pipeline of antisense-based drugs for the treatment of allergic diseases. These disorders are typically restricted to certain organs (the upper and lower respiratory tract, skin, gut, and eyes) not requiring systemic administration of medications, and there is still a strong medical need for novel causative acting drugs in this field.

\section{CONCLUSIONS}

In conclusion, the big advantage of antisense strategies is their target specificity. This makes the clinical application of antisense technologies highly attractive at a time when research on the pathogenesis of major diseases leads to identification of underlying molecular pathways and thus novel targets for therapeutic intervention. On the other hand, antisense technologies must overcome a number of challenges, including in vivo stability, drug delivery, and potential side and off-target effects. The recently published trials in disease areas, including infectious disease, chronic inflammatory conditions (including allergy and asthma), metabolic diseases, and several neurologic disorders, clearly indicate the increasing interest in the clinical application of antisense strategies. More and longer clinical trials are certainly warranted in most of these conditions to make antisense-based therapies clinically available. However, today it can be concluded that antisense-based therapies have the great opportunity to establish themselves as an additional column of therapeutic options in addition to biologicals and small molecules.

We thank Mrs Inge Schmidt and Mrs Jorun Braun for their secretarial and editorial assistance and Mrs Nesibe Akdağ for her help with figure preparation.

\section{REFERENCES}

1. Scherer LJ, Rossi JJ. Approaches for the sequence-specific knockdown of mRNA. Nat Biotechnol 2003;21:1457-65.

2. Goodchild J. Oligonucleotide therapeutics: 25 years agrowing. Curr Opin Mol Ther 2004;6:120-8.

3. Bennett CF, Swayze EE. RNA targeting therapeutics: molecular mechanisms of antisense oligonucleotides as a therapeutic platform. Annu Rev Pharmacol Toxicol 2010;50:259-93.

4. Burnett JC, Rossi JJ. RNA-based therapeutics: current progress and future prospects. Chem Biol 2012;19:60-71.

5. Winkler J. Oligonucleotide conjugates for therapeutic applications. Ther Deliv 2013;4:791-809.

6. Lundin KE, Gissberg O, Smith CI. Oligonucleotide therapies: the past and the present. Hum Gene Ther 2015;26:475-85.

7. Watts JK, Corey DR. Silencing disease genes in the laboratory and the clinic J Pathol 2012;226:365-79.

8. Farooqi AA, Rehman ZU, Muntane J. Antisense therapeutics in oncology: current status. Onco Targets Ther 2014;7:2035-42.

9. Karnati HK, Yalagala RS, Undi R, Pasupuleti SR, Gutti RK. Therapeutic potential of siRNA and DNAzymes in cancer. Tumour Biol 2014;35:9505-21.

10. Stephenson ML, Zamecnik PC. Inhibition of Rous sarcoma viral RNA translation by a specific oligodeoxyribonucleotide. Proc Natl Acad Sci U S A 1978;75:285-8.

11. Zamecnik PC, Stephenson ML. Inhibition of Rous sarcoma virus replication and cell transformation by a specific oligodeoxynucleotide. Proc Natl Acad Sci U S A $1978 ; 75: 280-4$.

12. Winkler J, Stessl M, Amartey J, Noe CR. Off-target effects related to the phosphorothioate modification of nucleic acids. ChemMedChem 2010;5:1344-52.
13. Yacyshyn BR, Bowen-Yacyshyn MB, Jewell L, Tami JA, Bennett CF, Kisner DL, et al. A placebo-controlled trial of ICAM-1 antisense oligonucleotide in the treatment of Crohn's disease. Gastroenterology 1998;114:1133-42.

14. Yacyshyn BR, Chey WY, Goff J, Salzberg B, Baerg R, Buchman AL, et al. Double blind, placebo controlled trial of the remission inducing and steroid sparing properties of an ICAM-1 antisense oligodeoxynucleotide, alicaforsen (ISIS 2302), in active steroid dependent Crohn's disease. Gut 2002;51:30-6.

15. Yacyshyn BR, Schievella A, Sewell KL, Tami JA. Gene polymorphisms and serological markers of patients with active Crohn's disease in a clinical trial of antisense to ICAM-1. Clin Exp Immunol 2005;141:141-7.

16. van Deventer SJ, Tami JA, Wedel MK. A randomised, controlled, double blind, escalating dose study of alicaforsen enema in active ulcerative colitis. Gut 2004;53:1646-51.

17. van Deventer SJ, Wedel MK, Baker BF, Xia S, Chuang E, Miner PB Jr. A phase II dose ranging, double-blind, placebo-controlled study of alicaforsen enema in subjects with acute exacerbation of mild to moderate left-sided ulcerative colitis. Aliment Pharmacol Ther 2006;23:1415-25.

18. Miner PB Jr, Wedel MK, Xia S, Baker BF. Safety and efficacy of two dose formulations of alicaforsen enema compared with mesalazine enema for treatment of mild to moderate left-sided ulcerative colitis: a randomized, double-blind, active-controlled trial. Aliment Pharmacol Ther 2006:23:1403-13.

19. Monteleone G, Neurath MF, Ardizzone S, Di SA, Fantini MC, Castiglione F, et al. Mongersen, an oral SMAD7 antisense oligonucleotide, and Crohn's disease. N Engl J Med 2015;372:1104-13.

20. Gauvreau GM, Boulet LP, Cockcroft DW, Baatjes A, Cote J, Deschesnes F, et al. Antisense therapy against CCR3 and the common beta chain attenuates allergen-induced eosinophilic responses. Am J Respir Crit Care Med 2008;177: 952-8.

21. Gauvreau GM, Pageau R, Seguin R, Carballo D, Gauthier J, D’Anjou H, et al, Dose-response effects of TPI ASM8 in asthmatics after allergen. Allergy 2011; 66:1242-8

22. Imaoka H, Campbell H, Babirad I, Watson RM, Mistry M, Sehmi R, et al. TPI ASM8 reduces eosinophil progenitors in sputum after allergen challenge. Clin Exp Allergy 2011;41:1740-6.

23. Homburg U, Renz H, Timmer W, Hohlfeld JM, Seitz F, Luer K, et al. Safety and tolerability of a novel inhaled GATA3 mRNA targeting DNAzyme in patients with TH2-driven asthma. J Allergy Clin Immunol 2015;136:797-800.

24. Krug N, Hohlfeld JM, Kirsten AM, Kornmann O, Beeh KM, Kappeler D, et al. Allergen-induced asthmatic responses modified by a GATA3-specific DNAzyme. N Engl J Med 2015;372:1987-95.

25. Amado RG, Mitsuyasu RT, Rosenblatt JD, Ngok FK, Bakker A, Cole S, et al. Antihuman immunodeficiency virus hematopoietic progenitor cell-delivered ribozyme in a phase I study: myeloid and lymphoid reconstitution in human immunodeficiency virus type-1-infected patients. Hum Gene Ther 2004;15:251-62.

26. MacPherson JL, Boyd MP, Arndt AJ, Todd AV, Fanning GC, Ely JA, et al. Long-term survival and concomitant gene expression of ribozyme-transduced CD4+ T-lymphocytes in HIV-infected patients. J Gene Med 2005;7:552-64.

27. Mitsuyasu RT, Merigan TC, Carr A, Zack JA, Winters MA, Workman C, et al. Phase 2 gene therapy trial of an anti-HIV ribozyme in autologous CD34+ cells. Nat Med 2009; 15:285-92.

28. Janssen HL, Reesink HW, Lawitz EJ, Zeuzem S, Rodriguez-Torres M, Patel K, et al. Treatment of $\mathrm{HCV}$ infection by targeting microRNA. N Engl J Med 2013;368:1685-94.

29. The Vitravene Study Group. A randomized controlled clinical trial of intravitreous fomivirsen for treatment of newly diagnosed peripheral cytomegalovirus retinitis in patients with AIDS. Am J Ophthalmol 2002;133:467-74.

30. The Vitravene Study Group. Randomized dose-comparison studies of intravitreous fomivirsen for treatment of cytomegalovirus retinitis that has reactivated or is persistently active despite other therapies in patients with AIDS. Am J Ophthalmol 2002;133:475-83.

31. The Vitravene Study Group. Safety of intravitreous fomivirsen for treatment of cytomegalovirus retinitis in patients with AIDS. Am J Ophthalmol 2002;133: 484-98.

32. DeVincenzo J, Cehelsky JE, Alvarez R, Elbashir S, Harborth J, Toudjarska I, et al. Evaluation of the safety, tolerability and pharmacokinetics of ALN-RSV01, a novel RNAi antiviral therapeutic directed against respiratory syncytial virus (RSV). Antiviral Res 2008;77:225-31.

33. DeVincenzo J, Lambkin-Williams R, Wilkinson T, Cehelsky J, Nochur S, Walsh E, et al. A randomized, double-blind, placebo-controlled study of an RNAi-based therapy directed against respiratory syncytial virus. Proc Natl Acad Sci U S A 2010;107:8800-5.

34. Zamora MR, Budev M, Rolfe M, Gottlieb J, Humar A, DeVincenzo J, et al. RNA interference therapy in lung transplant patients infected with respiratory syncytial virus. Am J Respir Crit Care Med 2011;183:531-8. 
35. Yu RZ, Geary RS, Flaim JD, Riley GC, Tribble DL, VanVliet AA, et al. Lack of pharmacokinetic interaction of mipomersen sodium (ISIS 301012), a 2'-O-methoxyethyl modified antisense oligonucleotide targeting apolipoprotein B-100 messenger RNA, with simvastatin and ezetimibe. Clin Pharmacokinet 2009;48:39-50.

36. Kastelein JJ, Wedel MK, Baker BF, Su J, Bradley JD, Yu RZ, et al. Potent reduction of apolipoprotein $\mathrm{B}$ and low-density lipoprotein cholesterol by short-term administration of an antisense inhibitor of apolipoprotein B. Circulation 2006;114:1729-35.

37. Raal FJ, Santos RD, Blom DJ, Marais AD, Charng MJ, Cromwell WC, et al. Mipomersen, an apolipoprotein B synthesis inhibitor, for lowering of LDL cholesterol concentrations in patients with homozygous familial hypercholesterolaemia: a randomised, double-blind, placebo-controlled trial. Lancet 2010;375: 998-1006.

38. Available at: http://www.fda.gov/NewsEvents/Newsroom/PressAnnouncements/ ucm337195.htm. Accessed July 15, 2015.

39. Fitzgerald K, Frank-Kamenetsky M, Shulga-Morskaya S, Liebow A, Bettencourt BR, Sutherland JE, et al. Effect of an RNA interference drug on the synthesis of proprotein convertase subtilisin/kexin type 9 (PCSK9) and the concentration of serum LDL cholesterol in healthy volunteers: a randomised, single-blind, placebo-controlled, phase 1 trial. Lancet 2014;383:60-8.

40. Graham MJ, Lee RG, Bell TA III, Fu W, Mullick AE, Alexander VJ, et al Antisense oligonucleotide inhibition of apolipoprotein C-III reduces plasma triglycerides in rodents, nonhuman primates, and humans. Circ Res 2013;112: 1479-90.

41. Nguyen QD, Schachar RA, Nduaka CI, Sperling M, Basile AS, Klamerus KJ, et al. Phase 1 dose-escalation study of a siRNA targeting the RTP801 gene in age-related macular degeneration patients. Eye (Lond) 2012;26:1099-105.

42. Nguyen QD, Schachar RA, Nduaka CI, Sperling M, Klamerus KJ, Chi-Burris K, et al. Evaluation of the siRNA PF-04523655 versus ranibizumab for the treatment of neovascular age-related macular degeneration (MONET Study). Ophthalmology 2012;119:1867-73.

43. Nguyen QD, Schachar RA, Nduaka CI, Sperling M, Basile AS, Klamerus KJ, et al. Dose-ranging evaluation of intravitreal siRNA PF-04523655 for diabetic macular edema (the DEGAS study). Invest Ophthalmol Vis Sci 2012;53:7666-74.

44. Kain H, Goldblum D, Geudelin B, Thorin E, Beglinger C. Tolerability and safety of GS-101 eye drops, an antisense oligonucleotide to insulin receptor substrate-1: a 'first in man' phase I investigation. Br J Clin Pharmacol 2009;68:169-73.

45. Cursiefen C, Bock F, Horn FK, Kruse FE, Seitz B, Borderie V, et al. GS-101 antisense oligonucleotide eye drops inhibit corneal neovascularization: interim results of a randomized phase II trial. Ophthalmology 2009;116:1630-7.

46. Cursiefen C, Viaud E, Bock F, Geudelin B, Ferry A, Kadlecova P, et al. Aganirsen antisense oligonucleotide eye drops inhibit keratitis-induced corneal neovascularization and reduce need for transplantation: the I-CAN study. Ophthalmology 2014;121:1683-92.

47. Moreno-Montanes J, Sadaba B, Ruz V, Gomez-Guiu A, Zarranz J, Gonzalez MV, et al. Phase I clinical trial of SYL040012, a small interfering RNA targeting beta-adrenergic receptor 2, for lowering intraocular pressure. Mol Ther 2014; 22:226-32.

48. Ormonde S, Chou CY, Goold L, Petsoglou C, Al-Taie R, Sherwin T, et al Regulation of connexin43 gap junction protein triggers vascular recovery and healing in human ocular persistent epithelial defect wounds. J Membr Biol $2012 ; 245: 381-8$

49. Coelho T, Adams D, Silva A, Lozeron P, Hawkins PN, Mant T, et al. Safety and efficacy of RNAi therapy for transthyretin amyloidosis. N Engl J Med 2013;369: 819-29.

50. van Deutekom JC, Janson AA, Ginjaar IB, Frankhuizen WS, Aartsma-Rus A, Bremmer-Bout $\mathrm{M}$, et al. Local dystrophin restoration with antisense oligonucleotide PRO051. N Engl J Med 2007:357:2677-86.

51. Goemans NM, Tulinius M, van den Akker JT, Burm BE, Ekhart PF, Heuvelmans $\mathrm{N}$, et al. Systemic administration of PRO051 in Duchenne's muscular dystrophy. N Engl J Med 2011;364:1513-22.

52. Voit T, Topaloglu H, Straub V, Muntoni F, Deconinck N, Campion G, et al. Safety and efficacy of drisapersen for the treatment of Duchenne muscular dystrophy (DEMAND II): an exploratory, randomised, placebo-controlled phase 2 study. Lancet Neurol 2014;13:987-96.

53. Limmroth V, Barkhof F, Desem N, Diamond MP, Tachas G. CD49d antisense drug ATL1102 reduces disease activity in patients with relapsing-remitting MS. Neurology 2014;83:1780-8.

54. Buller HR, Bethune C, Bhanot S, Gailani D, Monia BP, Raskob GE, et al. Factor $\mathrm{XI}$ antisense oligonucleotide for prevention of venous thrombosis. N Engl J Med 2015;372:232-40.

55. Monteleone G, Fantini MC, Onali S, Zorzi F, Sancesario G, Bernardini S, et al. Phase I clinical trial of Smad7 knockdown using antisense oligonucleotide in patients with active Crohn's disease. Mol Ther 2012;20:870-6.
56. Zorzi F, Calabrese E, Monteleone I, Fantini M, Onali S, Biancone L, et al A phase 1 open-label trial shows that smad7 antisense oligonucleotide (GED0301) does not increase the risk of small bowel strictures in Crohn's disease. Aliment Pharmacol Ther 2012;36:850-7.

57. Akdim F, Visser ME, Tribble DL, Baker BF, Stroes ES, Yu R, et al. Effect of mipomersen, an apolipoprotein B synthesis inhibitor, on low-density lipoprotein cholesterol in patients with familial hypercholesterolemia. Am J Cardiol 2010; 105:1413-9.

58. Akdim F, Stroes ES, Sijbrands EJ, Tribble DL, Trip MD, Jukema JW, et al Efficacy and safety of mipomersen, an antisense inhibitor of apolipoprotein B in hypercholesterolemic subjects receiving stable statin therapy. J Am Coll Cardiol 2010;55:1611-8.

59. Visser ME, Akdim F, Tribble DL, Nederveen AJ, Kwoh TJ, Kastelein JJ, et al, Effect of apolipoprotein-B synthesis inhibition on liver triglyceride content in patients with familial hypercholesterolemia. J Lipid Res 2010;51:1057-62.

60. Akdim F, Tribble DL, Flaim JD, Yu R, Su J, Geary RS, et al. Efficacy of apolipoprotein B synthesis inhibition in subjects with mild-to-moderate hyperlipidaemia. Eur Heart J 2011;32:2650-9.

61. McGowan MP, Tardif JC, Ceska R, Burgess LJ, Soran H, Gouni-Berthold I, et al Randomized, placebo-controlled trial of mipomersen in patients with severe hypercholesterolemia receiving maximally tolerated lipid-lowering therapy. PLoS One 2012;7:e49006.

62. Visser ME, Wagener G, Baker BF, Geary RS, Donovan JM, Beuers UH, et al Mipomersen, an apolipoprotein B synthesis inhibitor, lowers low-density lipoprotein cholesterol in high-risk statin-intolerant patients: a randomized, double-blind, placebo-controlled trial. Eur Heart J 2012;33:1142-9.

63. Stein EA, Dufour R, Gagne C, Gaudet D, East C, Donovan JM, et al Apolipoprotein B synthesis inhibition with mipomersen in heterozygous familial hypercholesterolemia: results of a randomized, double-blind, placebo-controlled trial to assess efficacy and safety as add-on therapy in patients with coronary artery disease. Circulation 2012;126:2283-92.

64. Thomas GS, Cromwell WC, Ali S, Chin W, Flaim JD, Davidson M. Mipomersen, an apolipoprotein B synthesis inhibitor, reduces atherogenic lipoprotein in patients with severe hypercholesterolemia at high cardiovascular risk: a randomized, double-blind, placebo-controlled trial. J Am Coll Cardiol 2013;62: 2178-84.

65. Li Z, Hard ML, Grundy JS, Singh T, von Moltke LL, Boltje I. Lack of clinical pharmacodynamic and pharmacokinetic drug-drug interactions between warfarin and the antisense oligonucleotide mipomersen. J Cardiovasc Pharmacol 2014;64: 164-71.

66. Glover JM, Leeds JM, Mant TG, Amin D, Kisner DL, Zuckerman JE, et al. Phase I safety and pharmacokinetic profile of an intercellular adhesion moleculeantisense oligodeoxynucleotide (ISIS 2302). J Pharmacol Exp Ther 1997;282: 1173-80.

67. Schreiber S, Nikolaus S, Malchow H, Kruis W, Lochs H, Raedler A, et al Absence of efficacy of subcutaneous antisense ICAM-1 treatment of chronic active Crohn's disease. Gastroenterology 2001;120:1339-46.

68. Yacyshyn B, Chey WY, Wedel MK, Yu RZ, Paul D, Chuang E. A randomized, double-masked, placebo-controlled study of alicaforsen, an antisense inhibito of intercellular adhesion molecule 1, for the treatment of subjects with active Crohn's disease. Clin Gastroenterol Hepatol 2007:5:215-20.

69. Miner P, Wedel M, Bane B, Bradley J. An enema formulation of alicaforsen, an antisense inhibitor of intercellular adhesion molecule-1, in the treatment of chronic, unremitting pouchitis. Aliment Pharmacol Ther 2004;19:281-6.

70. Maksymowych WP, Blackburn WD Jr, Tami JA, Shanahan WR Jr. A randomized, placebo controlled trial of an antisense oligodeoxynucleotide to intercellular adhesion molecule-1 in the treatment of severe rheumatoid arthritis J Rheumatol 2002;29:447-53.

71. Kahan BD, Stepkowski S, Kilic M, Katz SM, Van Buren CT, Welsh MS, et al Phase I and phase II safety and efficacy trial of intercellular adhesion molecule-1 antisense oligodeoxynucleotide (ISIS 2302) for the prevention of acute allograft rejection. Transplantation 2004;78:858-63.

72. DiGiusto DL, Krishnan A, Li L, Li H, Li S, Rao A, et al. RNA-based gene therapy for HIV with lentiviral vector-modified CD34 $(+)$ cells in patients undergoing transplantation for AIDS-related lymphoma. Sci Transl Med 2010;2:36ra43.

73. Tebas P, Stein D, Binder-Scholl G, Mukherjee R, Brady T, Rebello T, et al Antiviral effects of autologous CD4 $\mathrm{T}$ cells genetically modified with a conditionally replicating lentiviral vector expressing long antisense to HIV. Blood 2013; 121:1524-33.

74. Zhang R, Yan J, Shahinian HK, Amin G, Lu Z, Liu T, et al. Pharmacokinetics of an anti-human immunodeficiency virus antisense oligodeoxynucleotide phosphorothioate (GEM 91) in HIV-infected subjects. Clin Pharmacol Ther 1995;58:44-53.

75. Sereni D, Tubiana R, Lascoux C, Katlama C, Taulera O, Bourque A, et al Pharmacokinetics and tolerability of intravenous trecovirsen (GEM 91), an 
antisense phosphorothioate oligonucleotide, in HIV-positive subjects. J Clin Pharmacol 1999;39:47-54.

76. Gish RG, Satishchandran C, Young M, Pachuk C. RNA interference and its potential applications to chronic HBV treatment: results of a Phase I safety and tolerability study. Antivir Ther 2011;16:547-54.

77. Soler M, McHutchison JG, Kwoh TJ, Dorr FA, Pawlotsky JM. Virological effects of ISIS 14803, an antisense oligonucleotide inhibitor of hepatitis C virus (HCV) internal ribosome entry site (IRES), on HCV IRES in chronic hepatitis C patients and examination of the potential role of primary and secondary HCV resistance in the outcome of treatment. Antivir Ther 2004;9:953-68.

78. McHutchison JG, Patel K, Pockros P, Nyberg L, Pianko S, Yu RZ, et al. A phase I trial of an antisense inhibitor of hepatitis C virus (ISIS 14803), administered to chronic hepatitis C patients. J Hepatol 2006;44:88-96.

79. Henke JI, Goergen D, Zheng J, Song Y, Schuttler CG, Fehr C, et al. microRNA122 stimulates translation of hepatitis C virus RNA. EMBO J 2008;27:3300-10.

80. Available at: http://www.accessdata.fda.gov/drugsatfda_docs/nda/98/20961 Vitravene.cfm. Accessed October 12, 2015.

81. Libby P, Ridker PM, Maseri A. Inflammation and atherosclerosis. Circulation 2002; 105:1135-43.

82. Libby P. Inflammation in atherosclerosis. Nature 2002;420:868-74.

83. Hansson GK. Immune mechanisms in atherosclerosis. Arterioscler Thromb Vasc Biol 2001;21:1876-90.

84. Potaczek DP. Links between allergy and cardiovascular or hemostatic system. Int J Cardiol 2014;170:278-85.

85. Ladeiras-Lopes R, Agewall S, Tawakol A, Staels B, Stein E, Mentz RJ, et al Atherosclerosis: Recent trials, new targets and future directions. Int J Cardiol 2015;192:72-81.

86. Stein EA, Raal FJ. Targeting LDL: is lower better and is it safe? Best Pract Res Clin Endocrinol Metab 2014;28:309-24.

87. Gebhard C, Huard G, Kritikou EA, Tardif JC. Apolipoprotein B antisense inhibition-update on mipomersen. Curr Pharm Des 2013;19:3132-42.

88. Sahebkar A, Watts GF. New LDL-cholesterol lowering therapies: pharmacology, clinical trials, and relevance to acute coronary syndromes. Clin Ther 2013;35: 1082-98.

89. Santos RD, Raal FJ, Catapano AL, Witztum JL, Steinhagen-Thiessen E, Tsimikas S. Mipomersen, an antisense oligonucleotide to apolipoprotein B-100, reduces lipoprotein(a) in various populations with hypercholesterolemia: results of 4 phase III trials. Arterioscler Thromb Vasc Biol 2015;35:689-99.

90. Chappelow AV, Kaiser PK. Neovascular age-related macular degeneration: potential therapies. Drugs 2008;68:1029-36.

91. Barakat MR, Kaiser PK. VEGF inhibitors for the treatment of neovascula age-related macular degeneration. Expert Opin Investig Drugs 2009;18:637-46.

92. Singer M. Advances in the management of macular degeneration. F1000Prime Rep 2014;6:29.

93. Folkman J. Angiogenesis in cancer, vascular, rheumatoid and other disease. Nat Med 1995;1:27-31.

94. Kaiser PK, Symons RC, Shah SM, Quinlan EJ, Tabandeh H, Do DV, et al RNAi-based treatment for neovascular age-related macular degeneration by Sirna-027. Am J Ophthalmol 2010;150:33-9.

95. Shoshani T, Faerman A, Mett I, Zelin E, Tenne T, Gorodin S, et al. Identification of a novel hypoxia-inducible factor 1-responsive gene, RTP801, involved in apoptosis. Mol Cell Biol 2002;22:2283-93.

96. Brafman A, Mett I, Shafir M, Gottlieb H, Damari G, Gozlan-Kelner S, et al Inhibition of oxygen-induced retinopathy in RTP801-deficient mice. Invest Ophthalmol Vis Sci 2004;45:3796-805.

97. Delafontaine P, Song YH, Li Y. Expression, regulation, and function of IGF-1, IGF-1R, and IGF-1 binding proteins in blood vessels. Arterioscler Thromb Vasc Biol 2004:24:435-44.

98. Miele C, Rochford JJ, Filippa N, Giorgetti-Peraldi S, Van Obberghen E. Insulin and insulin-like growth factor-I induce vascular endothelial growth factor mRNA expression via different signaling pathways. J Biol Chem 2000;275 21695-702.

99. Andrieu-Soler C, Berdugo M, Doat M, Courtois Y, BenEzra D, Behar-Cohen F. Downregulation of IRS-1 expression causes inhibition of corneal angiogenesis. Invest Ophthalmol Vis Sci 2005;46:4072-8.

100. Al-Mahmood S, Colin S, Farhat N, Thorin E, Steverlynck C, Chemtob S. Poten in vivo antiangiogenic effects of GS-101 (5'-TATCCGGAGGGCTCGCCA
TGCTGCT-3'), an antisense oligonucleotide preventing the expression of insulin receptor substrate-1. J Pharmacol Exp Ther 2009;329:496-504.

101. Colin S, Darne B, Kadi A, Ferry A, Favier M, Lesaffre C, et al. The antiangiogenic insulin receptor substrate- 1 antisense oligonucleotide aganirsen impairs AU-rich mRNA stability by reducing 14-3-3beta-tristetraprolin protein complex, reducing inflammation and psoriatic lesion size in patients. J Pharmacol Exp Ther 2014;349:107-17.

102. Miller TM, Pestronk A, David W, Rothstein J, Simpson E, Appel SH, et al. An antisense oligonucleotide against SOD1 delivered intrathecally for patients with SOD1 familial amyotrophic lateral sclerosis: a phase 1, randomised, first-in-man study. Lancet Neurol 2013;12:435-42.

103. Leachman SA, Hickerson RP, Schwartz ME, Bullough EE, Hutcherson SL, Boucher KM, et al. First-in-human mutation-targeted siRNA phase Ib trial of an inherited skin disorder. Mol Ther 2010;18:442-6.

104. Aartsma-Rus A, Janson AA, Kaman WE, Bremmer-Bout M, van Ommen GJ, den Dunnen JT, et al. Antisense-induced multiexon skipping for Duchenne muscular dystrophy makes more sense. Am J Hum Genet 2004;74:83-92.

105. Smith RA, Miller TM, Yamanaka K, Monia BP, Condon TP, Hung G, et al. Antisense oligonucleotide therapy for neurodegenerative disease. J Clin Invest 2006; 116:2290-6.

106. Winer L, Srinivasan D, Chun S, Lacomis D, Jaffa M, Fagan A, et al. SOD1 in cerebral spinal fluid as a pharmacodynamic marker for antisense oligonucleotide therapy. JAMA Neurol 2013;70:201-7.

107. Brenner T, Hamra-Amitay Y, Evron T, Boneva N, Seidman S, Soreq H. The role of readthrough acetylcholinesterase in the pathophysiology of myasthenia gravis. FASEB J 2003;17:214-22.

108. Argov Z, McKee D, Agus S, Brawer S, Shlomowitz N, Yoseph OB, et al Treatment of human myasthenia gravis with oral antisense suppression of acetylcholinesterase. Neurology 2007;69:699-700.

109. Sussman JD, Argov Z, McKee D, Hazum E, Brawer S, Soreq H. Antisense treatment for myasthenia gravis: experience with monarsen. Ann N Y Acad Sci 2008;1132:283-90.

110. Sussman J, Argov Z, Wirguin Y, Apolski S, Milic-Rasic V, Soreq H. Further developments with antisense treatment for myasthenia gravis. Ann N Y Acad Sci 2012;1275:13-6.

111. Wypasek E, Potaczek DP, Alhenc-Gelas M, Undas A. PROS1 mutations associated with protein $S$ deficiency in Polish patients with residual vein obstruction on rivaroxaban therapy. Thromb Res 2014;134:199-201.

112. Wypasek E, Potaczek DP, Stapor R, Coucke PJ, De Backer J, De Paepe AM, et al. First report of the genetic background of Marfan syndrome in Polish patients. Pol Arch Med Wewn 2013;123:646-7.

113. Wypasek E, Potaczek DP, Alhenc-Gelas M, Undas A. Novel missense mutation C106R in the PROC gene associated with type I protein C deficiency in a young Polish man with high-risk pulmonary embolism. Pol Arch Med Wewn 2014;124: $75-6$.

114. Reitsma PH, Versteeg HH, Middeldorp S. Mechanistic view of risk factors for venous thromboembolism. Arterioscler Thromb Vasc Biol 2012;32:563-8.

115. Roque F, Mon G, Belardi J, Rodriguez A, Grinfeld L, Long R, et al. Safety of intracoronary administration of c-myc antisense oligomers after percutaneous transluminal coronary angioplasty (PTCA). Antisense Nucleic Acid Drug Dev 2001;11:99-106.

116. Kutryk MJ, Foley DP, van den Brand M, Hamburger JN, van der Giessen WJ, deFeyter PJ, et al. Local intracoronary administration of antisense oligonucleotide against c-myc for the prevention of in-stent restenosis: results of the randomized investigation by the Thoraxcenter of antisense DNA using local delivery and IVUS after coronary stenting (ITALICS) trial. J Am Coll Cardiol 2002;39:281-7.

117. Kipshidze N, Iversen P, Overlie P, Dunlap T, Titus B, Lee D, et al. First human experience with local delivery of novel antisense AVI-4126 with Infiltrator catheter in de novo native and restenotic coronary arteries: 6-month clinical and angiographic follow-up from AVAIL study. Cardiovasc Revasc Med 2007; $8: 230-5$.

118. Available at: http://www.ema.europa.eu/docs/en_GB/document_library/Summary_ of_opinion_-_Initial_authorisation/human/002429/WC500136279.pdf. Accessed October 27, 2015 .

119. Zhang YC, Taylor MM, Samson WK, Phillips MI. Antisense inhibition: oligonucleotides, ribozymes, and siRNAs. Methods Mol Med 2005;106:11-34. 